\title{
Phenotypic and Functional Characterization of T Cells from Patients with Myasthenia Gravis
}

\author{
Foroozan Mokhtarian, Marianne Pino, William Ofosu-Appiah, and David Grob \\ Division of Immunology, Department of Medicine, Maimonides Medical Center, and State University \\ of New York Health Science Center, Brooklyn, New York 11219
}

\section{Abstract}

A study of cell surface phenotypes of PBL of myasthenia gravis (MG) patients showed that their $T$ cells had a significantly higher percentage of $4 \mathrm{B4}^{+} \mathrm{T}$ cells (the helper/inducer subset) than age- and sex-matched controls. The PBL of MG patients proliferated significantly higher than those of normal subjects (NS) in response to the purified $\alpha$ chain of the acetylcholine receptor (AChR). Anti-AChR antibody was present in sera of $88 \%$ of MG and none of the NS. The PBL B cells from MG only, when cultured with autologous $T$ cells and stimulated with either pokeweed mitogen (69\%), or AChR- $\alpha$ chain (38\%), secreted antibody to $\mathrm{AChR}-\alpha$ chain, whereas $\mathrm{T}$ and $\mathrm{B}$ cells alone secreted no antibody.

T cells from PBL of MG patients were more readily cloned than $T$ cells of NS, by limiting dilution, in the presence of recombinant IL-2 and in the absence of AChR- $\alpha$ chain. About $\mathbf{5 0} \%$ of $\mathrm{T}$ cell clones from MG patients, compared to none from NS, proliferated to AChR- $\alpha$ chain. This response was HLADR restricted. MG $T$ cell clones did not display significant cytotoxic activity, as compared to control $T$ cell clones.

Our results indicate that in $\mathrm{MG}, 4 \mathrm{B4}^{+}$regulatory $\mathrm{T}$ cells play their role in the pathogenesis of MG, not by cytotoxicity, but more likely by their ability to stimulate specific antibody production by B cells. (J. Clin. Invest. 1990. 86:2099-2108.) Key words: acetylcholine receptor $\bullet$ myasthenia gravis $\bullet$ phenotyping • cell clones

\section{Introduction}

Myasthenia gravis (MG) ${ }^{1}$ is thought to be an autoimmune disease primarily mediated by antibodies to the acetylcholine receptor $(\mathrm{AChR})(1,2)$. The severity of the disease, however, does not correlate well with serum antibody levels (2). Many studies, including ours, have found that $T$ cells from the peripheral blood of MG patients respond, by lymphoproliferation, to AChR or AChR synthetic peptides, to a greater extent than do $T$ cells from normal subjects (3-6). $T$ cell lines responsive to AChR and/or its peptides have been isolated from

Address reprint requests to Dr. Mokhtarian, Division of Immunology, Department of Medicine, Maimonides Medical Center, Brooklyn, NY 11219.

Received for publication 8 February 1990 and in revised form 5 June 1990

1. Abbreviations used in this paper: $\mathrm{AChR}$, acetylcholine receptor; APC, antigen-presenting cell; LDA, limiting dilution analysis; MBP, myelin basic protein; MG, myasthenia gravis; MNC, mononuclear cells; MS, multiple sclerosis.

J. Clin. Invest.

(C) The American Society for Clinical Investigation, Inc.

0021-9738/90/12/2099/10 \$2.00

Volume 86, December 1990, 2099-2108 thymus as well as blood of MG patients (7-10). These lines, however, were all obtained by in vitro culture of $\mathrm{T}$ cells with antigens. Thus, the specific function of these $T$ cells and their involvement in the regulation of autoantibody production have not been fully elucidated.

This study was undertaken to characterize the peripheral blood lymphocytes (PBL) of MG patients both phenotypically and functionally in order to assess the immunoregulatory role of $\mathrm{T}$ cells in the pathogenesis of MG. With the availability of new monoclonal antibodies, CD4 and CD8 subsets of T cells have been found to be both functionally and phenotypically heterogenous (11-13). Through the use of monoclonal antibodies to CD4, CD8, 2H4, and 4B4 antigens, the $\mathrm{T}$ cells in PBL were further identified by the flow cytometry technique as supressor-inducer $\left(2 \mathrm{H}^{+}\right)$or helper-inducer $\left(4 \mathrm{~B} 4^{+}\right)$subsets. Clones of T cells were established from PBL of MG patients in the absence of the putative antigen, $A C h R$, to exclude in vitro sensitization to AChR. The aim of this study is to determine the function of these $T$ cells and their possible role in the pathogenesis of MG.

\section{Methods}

MG patients and controls for phenotypic studies. The clinical features of 17 patients with generalized MG, studied for phenotypic characterization, are shown in Table I. Three had mild weakness at the time of study, nine had moderate weakness, and five were severely weak and had difficulty breathing, swallowing, or getting out of bed. Three had previously had thymectomy, and two thymomectomy. Six were receiving prednisone daily. Only one patient (E.K.) was receiving azathioprine, $100-150 \mathrm{mg}$ daily orally, for $3 \frac{1}{2} \mathrm{mo}$. None had received plasmapheresis within a year of study. All except two patients had elevated serum levels of antibody to AChR, varying from 1 to $369 \mathrm{nmol} / \mathrm{liter}$. Nine normal subjects and 10 patients with multiple sclerosis (MS) of similar age and sex distribution were studied as controls. MS is an autoimmune disease of the central nervous system that has been phenotypically characterized and is thought to be a $\mathrm{T}$ cell-mediated disease.

Purification of $A C h R$. The AChR was purified from the tissues of Torpedo californica according to a previously described method (14, 15). After purification, the antigen was concentrated by ultrafiltration using a cell concentrator (Omega, Filtron, Clinton, MA). The purity of the recovered material was analyzed by SDS-PAGE on $7.5 \%$ gels under reducing conditions. One prominent band was seen in the area of $40,000-50,000 \mathrm{~mol} \mathrm{wt}$, which corresponded to the $\alpha$ chain of the receptor (Fig. 1). The presence of other AChR chains, however, cannot be ruled out completely $(14,15)$. Before use in cell culture studies, the antigen was dialyzed against $0.01 \mathrm{M}$ phosphate-buffered saline (PBS), $\mathrm{pH} 7.2$, to remove the detergent and the enzyme inhibitors. The purified $\alpha$ chain had a specific activity of $10^{-7} \mathrm{M} \alpha$-bungarotoxin binding sites per milligram of protein, as determined by a ${ }^{125} \mathrm{I}-\alpha$-bungarotoxin binding assay. The purified AChR has been used to induce experimental autoimmune MG in rats $(14,15)$.

Anti-AChR antibody assays of sera. Sera from patients with MG and from normal subjects were assayed for anti-AChR antibody, using ${ }^{125} \mathrm{I}$ - $\alpha$-bungarotoxin-labeled human AChR (16). This assay was performed by SmithKline Bioscience Inc., Sunnyvale, CA, and the titers 
Table I. Patients with Myasthenia Gravis

\begin{tabular}{|c|c|c|c|c|c|c|}
\hline \multirow{2}{*}{ Patient } & \multirow{2}{*}{ Sex } & \multirow{2}{*}{$\frac{\text { Age }}{y r}$} & \multirow{2}{*}{$\begin{array}{c}\begin{array}{c}\text { MG duration/ } \\
\text { severity }\end{array} \\
y r\end{array}$} & \multirow{2}{*}{$\begin{array}{l}\text { Years after } \\
\text { thymectomy }\end{array}$} & \multicolumn{2}{|c|}{ Prednisone } \\
\hline & & & & & $m g q d$ & $\operatorname{mo} R x$ \\
\hline D.R. & $\mathbf{M}$ & 61 & 4/mild & 0.2 & & \\
\hline G.G. & $\mathrm{F}$ & 65 & $7 / \mathrm{mild}$ & & & \\
\hline P.L. & $\mathbf{M}$ & 68 & $16 / \mathrm{mild}$ & & & \\
\hline E.D. & $\mathrm{F}$ & 24 & $3 /$ moderate & & & \\
\hline E.K. & $\mathrm{F}$ & 77 & $6 /$ moderate & $6^{*}$ & & \\
\hline G.H. & $\mathbf{M}$ & 61 & $7 /$ moderate & & 5 & 60 \\
\hline H.K. & $\mathbf{M}$ & 71 & $4 /$ moderate & & & \\
\hline J.M. & $\mathbf{M}$ & 66 & $5 /$ moderate & & & \\
\hline L.B. & $\mathrm{F}$ & 53 & $12 /$ moderate & 10 & & \\
\hline L.F. & $\mathbf{F}$ & 55 & $2 /$ moderate & & & \\
\hline R.C. & $\mathbf{M}$ & 66 & $3 /$ moderate & & & \\
\hline R.D. & F & 49 & $29 /$ moderate & & & \\
\hline C.C. & $\mathrm{F}$ & 34 & $7 /$ severe & & 40 & 4 \\
\hline D.M. & F & 30 & $11 /$ severe & 1 & 25 & 12 \\
\hline D.P. & $\mathbf{F}$ & 37 & $3 /$ severe & & 10 & 12 \\
\hline E.L. & $\mathbf{M}$ & 65 & $4 /$ severe & $5^{*}$ & 40 & 20 \\
\hline P.M. & $\mathbf{M}$ & 76 & $2 /$ severe & & 10 & 16 \\
\hline
\end{tabular}

* Thymomectomy.

were expressed as nanomoles of specific IgG per liter of serum. The AChR used in this study was extracted from human skeletal muscle and labeled with ${ }^{125} \mathrm{I}-\alpha$-bungarotoxin which specifically binds to the $\alpha$ region of $\mathrm{AChR}$. This complex was then incubated with the test sera to allow specific binding. The toxin-AChR-antibody complex was then immunoprecipitated with goat anti-human IgG. The amount of precipitated radioactivity is directly proportional to the titer of antiAChR antibody in the patient's serum.

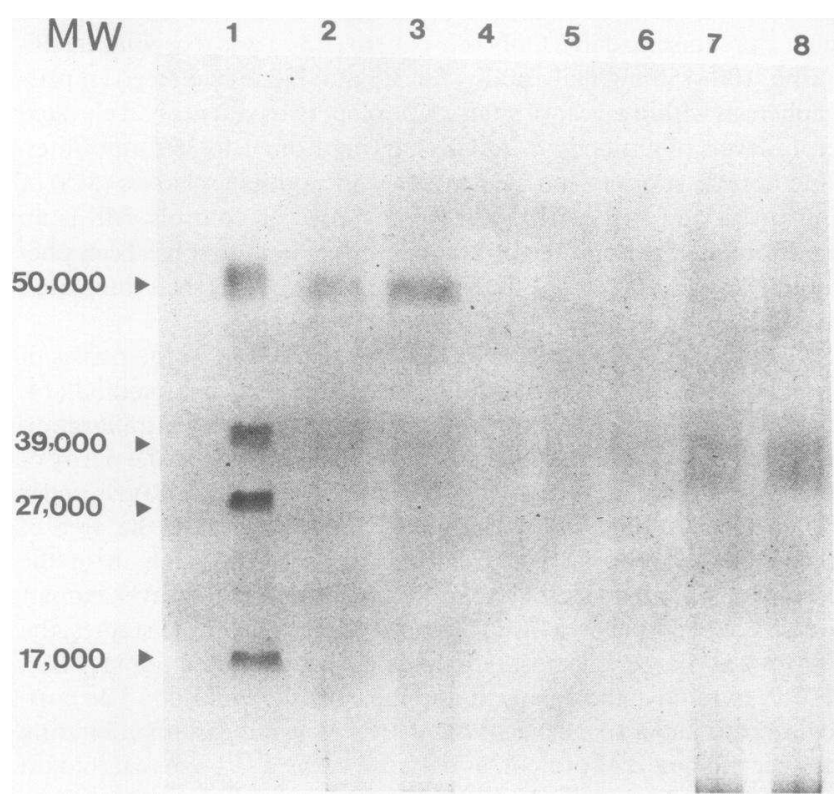

Figure 1. SDS-PAGE of purified AChR- $\alpha$ chain. Lane 1, molecular weight standards $(M W)$; lane 2, purified $\mathrm{AChR}, 25 \mu \mathrm{l}$; lane 3, purified AChR $50 \mu \mathrm{l}$; lane 4, effluent, $25 \mu \mathrm{l}$; lane 5, effluent, $50 \mu \mathrm{l}$; lane 6 , last eluate, $50 \mu \mathrm{l}$; lane 7 , crude receptor, $25 \mu \mathrm{l}$; lane 8 , crude receptor, $50 \mu$ l. See Methods for details.
Isolation, culture, and functional studies of lymphocyte populations. Mononuclear cells (MNC) were isolated from PBL by Lymphoprep (Accurate Chemical \& Scientific Corp., Westbury, NY) density gradient centrifugation (17). The band of MNC were then collected and washed twice in Hank's balanced salt solution (HBSS) and once in RPMI 1640 containing $2 \%$ fetal calf serum (FCS). The MNC were counted and were $>98 \%$ viable as assessed by trypan blue dye exclusion. $2 \times 10^{5}$ cells per well were then stimulated for lymphoproliferation, with purified AChR $(5 \mu \mathrm{g} / \mathrm{ml})$ and with irrelevant antigen, bovine serum albumin (BSA) $(50 \mu \mathrm{g} / \mathrm{ml})$ (Sigma Chemical Co. St. Louis, MO) as control, in 96-well round-bottom microtiter plates in $0.2 \mathrm{ml}$ of standard RPMI culture medium containing 10\% FCS and Hepes buffer. After $72 \mathrm{~h}$ of incubation, the cultures were labeled using $1 \mu \mathrm{Ci}$ of $\left[{ }^{3} \mathrm{H}\right]$ thymidine (Amersham Corp., Arlington Heights, IL) for $18 \mathrm{~h}$ and harvested onto glass-fiber filters and the amount of radioactivity was assessed by liquid scintillation spectroscopy. The results were expressed as counts per minute of $\left[{ }^{3} \mathrm{H}\right]$ thymidine incorporation in the presence or absence of AChR- $\alpha$ chain.

Separation of $T$ and $B$ lymphocytes. MNC were first depleted of adherent monocytes by passage through a Sephadex G-10 column (18). The nonadherent cells were incubated with 2-aminoethylisothiouronium hydrobromide-treated sheep red blood cells for $15 \mathrm{~min}$ at $37^{\circ} \mathrm{C}$, centrifuged at $50 \mathrm{~g}$ for $8 \mathrm{~min}$, and then incubated on ice for $1 \mathrm{~h}$ (19). The suspension was layered on Lymphoprep and centrifuged at $450 \mathrm{~g}$ for $45 \mathrm{~min}$. The B cell-enriched interphase was washed, resuspended in culture medium, and rosetted again to remove residual contaminating $\mathrm{T}$ cells. The rosetted $\mathrm{T}$ cells were freed of sheep erythrocytes by hypotonic lysis with buffered ammonium chloride solution. The $\mathrm{T}$ cell-enriched population contained $>98 \% \mathrm{E}^{+}$rosette-forming cells. The $\mathrm{B}$ cell population comprised $>95 \% \mathrm{E}^{-}$cells and occasional $(<0.1 \%)$ monocytes/macrophages as evidenced by differential staining with Wright-Giemsa. An indirect immunofluorescence assay, using anti-CD3 and anti-IgG antibodies, was employed to check the purity of the cell separation. The number of each cell population was determined by counting the number of positive and negative cells. The results showed that the $\mathrm{E}^{+}$cells contained $2.5 \% \mathrm{IgG}^{+}$and $97 \% \mathrm{CD}^{+}$ cells. The $\mathrm{E}^{-}$cells contained $95 \% \mathrm{IgG}^{+}$and $6 \% \mathrm{CD}^{+}$cells. Since the culture of neither $B$ cells or $T$ cells alone, from antibody-positive lymphocyte cultures of MG patients, produced antibody to AChR, the separation technique was considered adequate.

Production of anti-AChR- $\alpha$ chain antibody in vitro. Purified T cells $\left(2 \times 10^{4} / \mathrm{ml}\right)$ from $29 \mathrm{MG}$ patients, $10 \mathrm{MS}$ patients, and 10 normal subjects and their purified autologous $B$ cells $\left(5 \times 10^{4} / \mathrm{ml}\right)$ were cultured, either alone or together, in the presence of $10 \mu \mathrm{g} / \mathrm{ml} \mathrm{AChR}-\alpha$ chain or $12.5 \mu \mathrm{g} / \mathrm{ml}$ pokeweed mitogen (PWM, Sigma Chemical Co.). The cells were cultured for $9 \mathrm{~d}$ in culture medium in 96 -well roundbottomed microtiter plates (20). Cultures containing AChR were incubated for $4 \mathrm{~d}$, at which time the medium was removed, to remove free AChR which might combine with the synthesized antibody, and recultured in antigen-free medium for $5 \mathrm{~d}$. At the end of culture, the supernatants were harvested and concentrated 50-fold, using B 15 concentrators (Amicon Corp., Danvers, MA) and stored at $-80^{\circ} \mathrm{C}$ until tested for anti-AChR- $\alpha$ chain antibody.

Measurement of anti-AChR- $\alpha$ chain antibody produced in vitro The anti-AChR- $\alpha$ chain antibody was measured by a sensitive enzyme-linked immunosorbent assay (ELISA), in which the microtiter wells were coated with $\mathrm{AChR}-\alpha$ chain $(1 \mu \mathrm{g} / \mathrm{ml})$ or control antigen, myelin basic protein (MBP). This MBP, routinely purified in our laboratory from guinea pig spinal cords, is being successfully used to determine antibody in the sera of mice and MS patients (21). The concentrated supernatants $(200 \mu \mathrm{l})$, in duplicate, were incubated on these solid-phase antigens for $24-48 \mathrm{~h}$ at $4^{\circ} \mathrm{C}$. Wells containing buffer alone served as background control. All plates were washed three times with PBS- $0.05 \%$ Tween 20 , and $100 \mu \mathrm{l}$ of alkaline phosphatase-conjugated anti-human IgG, diluted 1:500, was added and incubated for a further $90 \mathrm{~min}$ at $37^{\circ} \mathrm{C}$. After washing, $200 \mu \mathrm{l}$ of enzyme substrate $p$-nitrophenylphosphate was added to each well and incubated for $30 \mathrm{~min}$. The results were read at optical density (OD) of $410 \mathrm{~nm}$, using a 
spectrophotometer (Dynatech Laboratories, Inc., Alexandria, VA). The amount of antibody in nanograms per milliliter was determined on the basis of a standard curve constructed by plotting the ODs against the known concentrations of an anti-AChR monoclonal antibody MAb-35 (see below). Patients' (and normal subjects') culture supernatants were considered positive if their values exceeded mean +2 SD of control supernatants. Samples were assayed in duplicate and if the values were not within $10 \%$ of each other they were then repeated in triplicate.

Production and purification of anti-AChR monoclonal antibody. MAb-35, a rat hybridoma cell line which produces an IgG antibody reactive with $\mathrm{AChR}$, was purchased from American Type Culture Collection, Rockville, MD. The cells were grown in culture and the supernatants concentrated by ultrafiltration (Amicon Corp.). The IgG in the culture supernatants was partially purified by precipitation with $50 \%$ saturated ammonium sulfate (22), followed by immediate dialysis into PBS, pH 7.2 (Gibco Laboratories, Grand Island, NY). The partially purified material was further purified by passage through a protein-A Sepharose 4B column (Pharmacia, Inc., Piscataway, NJ). Elution with $0.1 \mathrm{M}$ glycine- $\mathrm{HCl}, \mathrm{pH} 3.0$, was performed after extensive washing of the column with PBS. The MAb eluted from the column was immediately neutralized with $1.0 \mathrm{M}$ Tris- $\mathrm{NaCl}, \mathrm{pH} 8.0$. After dialysis against $\mathrm{PBS}$, the antibody was aliquotted and stored at $-20^{\circ} \mathrm{C}$. The concentration of the MAb was calculated using a standard curve obtained with purified rat IgG (Accurate Chemical and Scientific Corp.). The purified IgG anti-AChR antibody was used as a standard in the ELISA assays.

Cloning of $I L-2$ responsive cells. Lymphocytes were cloned, using limiting dilution analysis (LDA) (23) in 96-well round-bottomed microtitre plates at $0.3-3$ cells per well in the presence of $10^{4}$ autologous mitomycin-C (Sigma Chemical Co.)-treated MNC (as feeder cells) in RPMI 1640 containing 10\% FCS and $15 \mathrm{U} / \mathrm{ml}$ of recombinant IL-2 (rIL-2, Genzyme, Boston, MA). The feeder cells were prepared by incubation of $2-5 \times 10^{6}$ autologous peripheral blood mononuclear cells (PBMC) per milliliter with $50 \mu \mathrm{g}$ of mitomycin $\mathrm{C}$ for $40 \mathrm{~min}$ at $37^{\circ} \mathrm{C}$ (24). 24 replicate cultures were set up for each cell concentration and incubated at $37^{\circ} \mathrm{C}$ in $5 \% \mathrm{CO}_{2} / 95 \%$ air. The cultures were fed on day 7 by replacing $0.1 \mathrm{ml}$ of growth medium with fresh IL-2 containing medium. After a further $7 \mathrm{~d}$ in culture, the microtiter wells were scored microscopically and the ones that contained growth were picked and expanded in fresh IL-2 medium. Cultures in which growth was seen in the control feeder cells alone were discarded. Poisson distribution analysis was used to identify those populations arising from single precursors (i.e., input cell density giving $>37 \%$ negative wells). Therefore clones were picked from less than one cell per well for this study. In many instances, when an already established clone was very small or was not growing well, $5 \mu \mathrm{g} / \mathrm{ml}$ of phytohemagglutinin (PHA), together with feeder cells, was added to the culture. The clones were fed with fresh medium every 2-3 d and feeder cells plus PHA $(5 \mu \mathrm{g} / \mathrm{ml})$ when their growth had stopped. After 8 wk in culture, the growth and functional properties of most clones started to decline.

Phenotyping of $T$ cell clones. The surface antigenic phenotype of PBL and $T$ cell clones were tested by an immunofluorescence assay using mouse anti-human CD4, CD8, 2H4, and 4B4 MAb (Coulter Immunology, Hialeah, FL). PBL $\left(1 \times 10^{6}\right)$ and T cell clones $\left(1 \times 10^{5}\right.$ were incubated with 1:40 dilution of each of the MAb at $4^{\circ} \mathrm{C}$ for 30 min and washed twice with PBS containing $2 \%$ FCS and $0.1 \%$ sodium azide. Fluorescein isothiocyanate (FITC)-conjugated anti-mouse IgG was then added at $1: 100$ dilution to all cells and incubated at $4^{\circ} \mathrm{C}$ for 30 min. The cells were then washed three times with PBS, fixed with $1 \%$ paraformaldehyde for $10 \mathrm{~min}$, and washed again, and the cell surface immunofluorescence was assessed by flow cytometry. The latter analysis was performed on a Cytofluorograph IIs (Ortho Diagnostic Systems, Inc., Raritan, NJ) and the cells were gated on forward and rightangle scatter. Approximately $10^{5}$ cells were counted and the results were expressed as the percentage of positively stained cells. The background (percentage of cells stained with normal mouse IgG) was subtracted in each instance.
Proliferation assays of clones. Before the functional studies, the T cell clones were "rested" for $14 \mathrm{~d}$ after the last addition of feeder cells. At that time, no feeder cells were present in the clones. The clones were washed twice in medium without IL-2 and incubated overnight in IL-2-free medium to remove residual IL-2. The T cell clones $\left(1 \times 10^{4}\right)$ were cultured with $5 \mu \mathrm{g} / \mathrm{ml}$ of specific antigen, AChR, or $50 \mu \mathrm{g} / \mathrm{ml}$ of control antigens, MBP or BSA, in the presence of $5 \times 10^{4}$ irradiated (50 Gy) PBMC as antigen-presenting cells (APC) in 96-well round-bottom microtiter plates in $0.2 \mathrm{ml}$ of medium in the absence of IL-2. A positive control of the clones' response to IL-2 and a negative control of clones plus APC alone were included in each assay. In some experiments MBP-responsive clones were included to confirm the antigenicity of this antigen.

To check that the proliferative response to AChR by the T cell clones is not due to APC, the APC alone was also exposed to AChR. After $72 \mathrm{~h}$ of incubation, the cultures were labeled using $1 \mu \mathrm{Ci}$ of $\left[{ }^{3} \mathrm{H}\right]$ thymidine for $18 \mathrm{~h}$ harvested onto glass-fiber filters, and the amount of radioactivity was assessed by liquid scintillation spectroscopy. Because of limited growth of the $\mathrm{T}$ cell clones, only in some experiments were we able to perform MHC-restriction studies using anti-HLA antibodies. In such studies $20 \mu \mathrm{l}$ of anti-HLA-DR and anti-HLA-ABC (shared determinants) antibodies (Accurate Chemical \& Scientific Corp.) were added to $T$ cell clones and cultured for $3 \mathrm{~d}$ with and without AChR. Lymphoproliferation was evaluated as described above.

Cytotoxic assay. The cytotoxic activity of the $\mathrm{T}$ cell clones was determined in a 4-h chromium ${ }^{51} \mathrm{Cr}$-release assay as previously described (25), using K562 and Daudi tumor cells (American Type Culture Collection) as targets. The target cells $\left(5 \times 10^{6}\right)$ were labeled with $150 \mu \mathrm{Ci} \mathrm{Na}{ }^{51} \mathrm{CrO}_{4}$ (Amersham Corp.) in $0.2 \mathrm{ml}$ of medium for $60 \mathrm{~min}$ in a $37^{\circ} \mathrm{C}$ water bath. After incubation, the target cells were washed twice with HBSS and suspended at $10^{5} \mathrm{cells} / \mathrm{ml}$ in complete medium without IL-2, and $100 \mu \mathrm{l}$ was added to round-bottomed tubes to give $10^{4}$ cells/well. T cell clones were added to the targets in each well to give effector/target ratios of 5:1, 10:1, and 20:1. The tubes were centrifuged at $45 \mathrm{~g}$ for $3 \mathrm{~min}$ and incubated at $37^{\circ} \mathrm{C}$ in $5 \% \mathrm{CO}_{2}$ for $4 \mathrm{~h}$. Maximum and spontaneous release of ${ }^{51} \mathrm{C} \cdot \dot{r}$ was determined by adding respectively $100 \mu \mathrm{l}$ of $2 \%$ Triton-X100 and medium alone to the targets. After incubation, the tubes were centrifuged at $150 \mathrm{~g}$ for $10 \mathrm{~min}$ and $100 \mu \mathrm{l}$ of supernatant was removed and counted for radioactivity in a Beckman $5500 \mathrm{~B} \gamma$-counter (model 5500B, Beckman Instruments, Inc., Fullerton, CA). In all experiments the spontaneous release was always $<10 \%$ of the maximum release. The results are expressed as: $\%$ specific cytotoxicity $=($ test release - spontaneous release $\times 100)$ ) (maximum release - spontaneous release).

\section{Results}

Phenotypic analysis of $P B L$. The surface phenotypes of the PBL of 17 MG patients (described in Table I) and 19 controls (9 normal subjects and 10 patients with MS) are listed in Tables II and III, respectively. Patients with MG did not differ from normal subjects and MS patients in the percentage of CD4 and CD8 cells in their PBL. MG patients, however, exhibited a significantly higher percentage of $4 \mathrm{~B} 4^{+}$cells, the helper-inducer subset, than normal subjects $(P<0.001)$. The percentage of $2 \mathrm{H}^{+}$cells, the cytotoxic/suppressor-inducer subset, though lower than in normal subjects, was not significantly different (Table II). In contrast, the percentage of $2 \mathrm{H}^{+}$ cells in MS patients was significantly lower $(P=0.01)$ than in normal subjects, whereas the percentage of $4 \mathrm{~B}^{+}$cells was not significantly different (Table III). The differences between these two T cell subsets in MG and MS patients were not statistically significant.

Patients with mild or moderate severity of MG appeared to have a higher percentage of $4 \mathrm{~B} 4^{+} \mathrm{T}$ cells than patients with 
Table II. Cell Surface Phenotypes of PBL of MG Patients

\begin{tabular}{|c|c|c|c|c|c|}
\hline \multirow[b]{2}{*}{ MG patients } & \multicolumn{4}{|c|}{ Positive phenotype } & \multirow{2}{*}{$\begin{array}{c}\text { Serum } \\
\text { antibody } \\
\text { to } \mathrm{AChR}\end{array}$} \\
\hline & CD4 & CD8 & $4 B 4^{*}$ & $2 \mathrm{H} 4$ & \\
\hline & \multicolumn{4}{|c|}{$\%$} & nmol/liter \\
\hline D.R. & 46.8 & 18.5 & 72.3 & 36.9 & 4 \\
\hline G.G. & 49.8 & 20.1 & 77.4 & 42.2 & 10 \\
\hline P.L. & 49.7 & 29.5 & 79.1 & 42.9 & 1.5 \\
\hline E.D. & 32.2 & 10.9 & 52.3 & 30.7 & 1 \\
\hline E.K. & 39.5 & 15.7 & 65.4 & 57.5 & 4 \\
\hline G.H. & 48.7 & 29.1 & 83.8 & 52.6 & 14 \\
\hline H.K. & 28.3 & 27.9 & 74.6 & 54.0 & 9 \\
\hline J.M. & 49.2 & 17.6 & 84.7 & 46.7 & 13 \\
\hline L.B. & 63.7 & 17.2 & 84.2 & 40.0 & $<0.5$ \\
\hline L.F. & 37.8 & 14.3 & 62.3 & 36.0 & 3 \\
\hline R.C. & 63.2 & 13.4 & 79.9 & 48.0 & 20 \\
\hline R.D. & 34.7 & 22.1 & 66.7 & 38.0 & $<0.5$ \\
\hline C.C. & 55.6 & 14.3 & 66.4 & 47.9 & 7 \\
\hline D.M. & 10.8 & 18.0 & 73.2 & 50.1 & 76 \\
\hline D.P. & 40.5 & 20.0 & 57.6 & 50.5 & 369 \\
\hline E.L. & 61.9 & 15.2 & 54.7 & 45.4 & 6 \\
\hline P.M. & 44.9 & 22.8 & 91.3 & 39.6 & 13 \\
\hline Mean \pm SD & $44.5 \pm 13.6$ & $19.2 \pm 5.5$ & $72.1 \pm 11.4$ & $44.6 \pm 7.2$ & \\
\hline
\end{tabular}

* $P<0.001 \mathrm{MG}$ higher than normal.

Table III. Cell Surface Antigens in Patients with MS and in Normal Subjects

\begin{tabular}{|c|c|c|c|c|}
\hline \multirow[b]{2}{*}{ Patient no. } & \multicolumn{4}{|c|}{ Positive cells } \\
\hline & CD4 & CD8 & $4 \mathrm{~B} 4$ & $2 \mathrm{H} 4^{*}$ \\
\hline & \multicolumn{4}{|c|}{$\%$} \\
\hline \multicolumn{5}{|l|}{ MS } \\
\hline 1 & 38.5 & 22.3 & 78.0 & 31.1 \\
\hline 2 & 34.3 & 31.0 & 69.8 & 42.9 \\
\hline 3 & 30.6 & 17.8 & 51.7 & 37.4 \\
\hline 4 & 47.5 & 15.2 & 57.1 & 45.0 \\
\hline 5 & 45.1 & 19.1 & 84.5 & 37.6 \\
\hline 6 & 53.9 & 7.1 & 41.5 & 42.5 \\
\hline 7 & 63.2 & 21.6 & 58.7 & 45.3 \\
\hline 8 & 52.9 & 16.4 & 57.7 & 35.8 \\
\hline 9 & 42.9 & 24.3 & 43.0 & 45.9 \\
\hline 10 & 32.0 & 17.8 & 42.8 & 29.7 \\
\hline Mean \pm SD & $44.1 \pm 10.6$ & $19.3 \pm 6.3$ & $58.5 \pm 14.9$ & $39.3 \pm 5.9$ \\
\hline \multicolumn{5}{|c|}{ Normal subjects } \\
\hline 1 & 45.4 & 21.6 & 51.8 & 56.9 \\
\hline 2 & 51.3 & 16.7 & 63.4 & 54.0 \\
\hline 3 & 34.3 & 22.6 & 52.6 & 52.2 \\
\hline 4 & 47.6 & 18.4 & 56.6 & 60.5 \\
\hline 5 & 33.2 & 21.7 & 45.0 & 50.6 \\
\hline 6 & 31.7 & 28.1 & 43.3 & 46.1 \\
\hline 7 & 20.2 & 15.8 & 63.7 & 47.0 \\
\hline 8 & 57.0 & 4.9 & 65.0 & 41.2 \\
\hline 9 & 36.6 & 27.1 & 59.1 & 41.8 \\
\hline Mean \pm SD & $39.7 \pm 11.5$ & $21.5 \pm 4.5$ & $54.5 \pm 7.2$ & $50.0 \pm 6.6$ \\
\hline
\end{tabular}

${ }^{*} P=0.01$. severe weakness. The latter group of patients, however, were all receiving daily prednisone, which can affect their percentage of responding cells (Tables I and II).

Peripheral blood humoral and cellular responses to $A C h R$. Antibody to AChR was significantly elevated in the sera of 15 of $17(88 \%)$ of MG patients (Table II) and none of 9 normal subjects, who consistently had a level of $<0.5 \mathrm{nmol} /$ liter (data not shown). Patients with severe MG of shorter duration displayed the highest levels of anti-AChR antibody in their sera (Table II).

The lymphoproliferative responses to purified AChR- $\alpha$ chain of PBL from 17 patients with MG and 11 normal subjects are presented in Fig. 2 . Any cpm $>3 \times 10^{3}$ (mean normal subjects $+2 \mathrm{SD}$ ) was considered to be significantly elevated. The PBL of $11 \mathrm{MG}$ patients $(65 \%)$ and one normal subject (9\%) proliferated to AChR above this level (Fig. 2).

To study the separate roles of $\mathrm{T}$ and $\mathrm{B}$ cells in the production of antibody to AChR- $\alpha$ chain, these cells were separated, purified, and cultured either separately or together, in the presence of either AChR or PWM and antibody production was measured (Fig. 3). Detectable amounts of anti-AChR- $\alpha$ chain antibody were produced only when autologous $T$ and $B$ cells from MG patients were cultured together. The level of antiAChR antibody synthesis was higher with the T cell-dependent B cell polyclonal activator, PWM, than with AChR- $\alpha$ chain. Purified T cells from PBL of 11 of 29 MG patients (38\%) when stimulated with AChR- $\alpha$ chain, and 20 of 29 MG patients (69\%) when stimulated with PWM, helped the autolo-

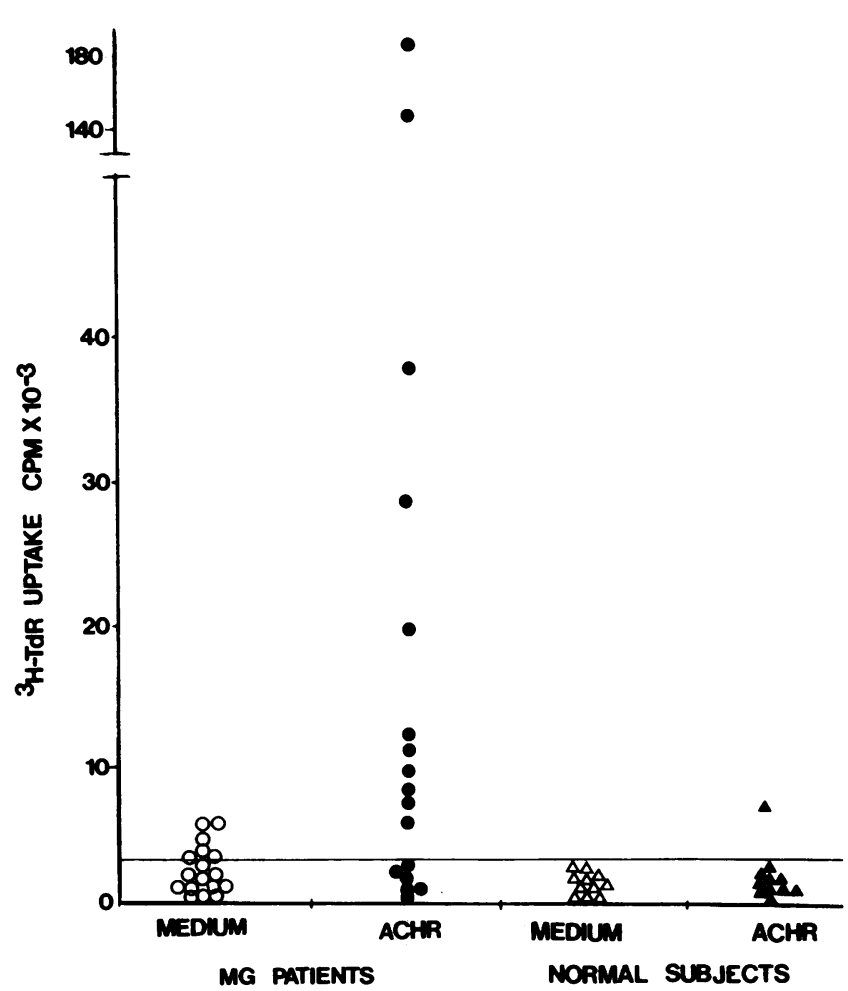

Figure 2. Proliferative responses of PBL to AChR- $\alpha$ chain. The responses of $17 \mathrm{MG}$ patients and 11 normal subjects to purified AChR- $\alpha$ chain are shown as counts per minute of $\left[{ }^{3} \mathrm{H}\right]$ thymidine uptake $\left(\times 10^{-3}\right)$ of lymphocytes in the presence and absence of AChR- $\alpha$ chain $(P=0.05)$. Values $>3 \times 10^{-3} \mathrm{cpm}$ (mean of normal subjects $+2 \mathrm{SD}$ ) are considered positive. 
gous B cells secrete anti-AChR- $\alpha$ chain antibody in vitro (Fig. 3). Unseparated PBL from 3 of $29 \mathrm{MG}$ patients (10\%), when stimulated with AChR- $\alpha$ chain, and 13 of 29 MG patients (45\%), when stimulated with PWM, produced slightly elevated levels of anti-AChR- $\alpha$ chain antibody in the culture supernatants (Fig. 3). The antibody, synthesized in vitro, was specific for AChR- $\alpha$ chain since it did not bind to the irrelevant antigen, MBP. Anti-AChR- $\alpha$ chain antibody was not detectable in supernatants from cultures of PBL of normal subjects and MS patients (Fig. 3). Culture supernatants from T or B cells alone of $M G$ patients, stimulated with either AChR- $\alpha$ chain or PWM, all gave values of $<1 \mathrm{ng} / \mathrm{ml}$ of antiAChR antibody, which did not differ from the concentration of unstimulated $\mathrm{T}$ or B cell cultures of MG patients (data not shown).

Generation of $I L-2$ responsive $T$ cell clones. $\mathrm{PBL}$ from nine patients with MG and eight normal subjects were cloned by LDA in IL-2 medium without prior activation with AChR- $\alpha$ chain. Most cultures from patients with MG yielded some growth at less than one cell per well while cultures from normal subjects required $200-400$ cells per well (Table IV). Thus, MG patients had a much higher precursor frequency of IL-2responsive cells than normal subjects, and hence could be

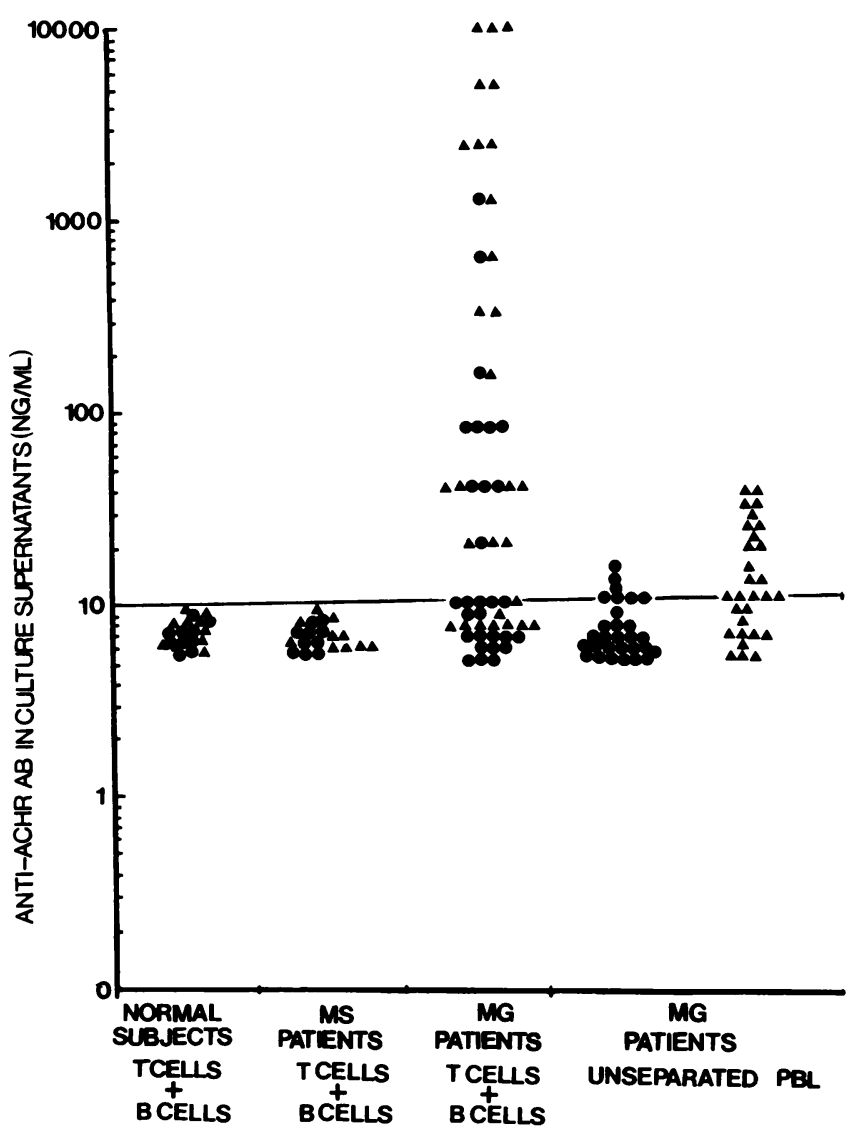

Figure 3. Anti-AChR- $\alpha$ chain antibody production of $\mathrm{T}$ and $\mathrm{B}$ cells. The supernatants of unseparated PBL and of purified T and B cells, cultured together and stimulated with AChR- $\alpha$ chain ( $\bullet$ ) and PWM (A) for $9 \mathrm{~d}$. The amount of IgG secreted was determined by ELISA and expressed as nanograms per milliliter. The solid line across the graph at $10 \mathrm{ng} / \mathrm{ml}$ is the mean $+2 \mathrm{SD}$ for normal subjects. Cultures of $\mathrm{T}$ or B cells alone, stimulated either with AChR or PWM, gave values $<0.1 \mathrm{ng} / \mathrm{ml}$. See Methods for details.
Table IV. Frequencies of In Vivo Activated IL-2-dependent Cells in PBL by $L D A$

\begin{tabular}{lc}
\hline \multicolumn{1}{c}{ Cell source } & $\begin{array}{c}\text { Mean precursor frequency } \\
\text { (range) }\end{array}$ \\
\hline MG patients PBL $(n=9)$ & $1 / 1.0 \pm 0.3(0.3-3.0$ cells) \\
Normal subjects PBL $(n=8)$ & $1 / 400 \pm 70(200-520$ cells) \\
\hline
\end{tabular}

Precursor frequencies are expressed as the reciprocal of mean \pm SD of the number of cells per well that grew out a clone.

more readily cloned. The clone sizes were very small at the end of the culture period. All the clones were subsequently expanded with mitomycin C-treated autologous feeder cells and PHA and clones of larger size and numbers of cells were obtained after $21 \mathrm{~d}$.

The results of LDA of IL-2-responsive T cells is shown in Fig. 4. The linear regression of the curves, plotted as number of cells against the logarithm of the fraction of nonresponsive cultures (Fnr) indicates that precursors of IL-2-responsive T cells were limiting in these cultures. This profile is consistent with a single-hit phenomenon (26). Thus, by applying Poisson distribution analysis, the precussor frequency or likelihood of monoclonability could be determined from the line at Fnr $=0.37$, at one cell per well for MG patients and at 400 cells per well for normal subjects. Since the MG clones were picked and expanded from less than one cell per well, the majority, but not all of the growth obtained was considered monoclonal. When tested by FACS, $\sim 85 \%$ of $\mathrm{T}$ cell clones from MG patients were found to be $\geq 95 \%$ homogenous (either CD4 or CD8), whereas only $\sim 20-30 \%$ of cell growth in cultures of lymphocytes from normal subjects were homogeneous and the rest had to be either recloned or discarded. Multiple attempts had to be made in order to obtain $\mathrm{T}$ cell clones from normal subjects under our experimental conditions.

Phenotypic analysis of $T$ cell clones. 14 of the $21 \mathrm{~T}$ cell clones $(70 \%)$ obtained from 9 MG patients expressed CD8 antigens, and 7 (30\%) expressed CD4 on their surfaces (data not shown). The surface phenotypes of the nine clones from seven MG patients which were responsive to AChR- $\alpha$ chain in the lymphoproliferation assay (see below), are shown in Table V. Of these nine clones, five were $\mathrm{CD}^{+}$and four were $\mathrm{CD}^{+}$. The surface phenotype of the $\mathrm{T}$ cell clones obtained from five normal subjects was predominantly CD8 $(8 / 9$ or $90 \%)$, with CD4 antigen being expressed on only one clone (1/9 or $10 \%)$. The clones were further analyzed for the expression of $2 \mathrm{H} 4$ and 4B4 antigens, which define the supressor-inducer and helper-inducer subsets, respectively. Five of nine clones from MG patients and four of nine from normal subjects expressed only 4B4 antigen on their surface (Table V). Three of nine clones from MG patients and three of nine from normal subjects expressed both $4 \mathrm{~B} 4$ and $2 \mathrm{H} 4$ antigens on their surface. A clone from one normal subject and none from MG patients expressed $2 \mathrm{H} 4$ antigen in the absence of $4 \mathrm{~B} 4$ antigen, and one clone from each group expressed only CD8 antigen.

Proliferative responses of $T$ cell clones to $A C h R .19 \mathrm{~T}$ cell clones isolated from 9 patients with MG, and 9 clones from 8 normal subjects were stimulated with purified AChR- $\alpha$ chain, IL-2, and MBP. Of the $19 \mathrm{~T}$ cell clones, nine from seven different MG patients proliferated significantly to purified AChR- $\alpha$ chain (Table VI). None of the T cell clones from 


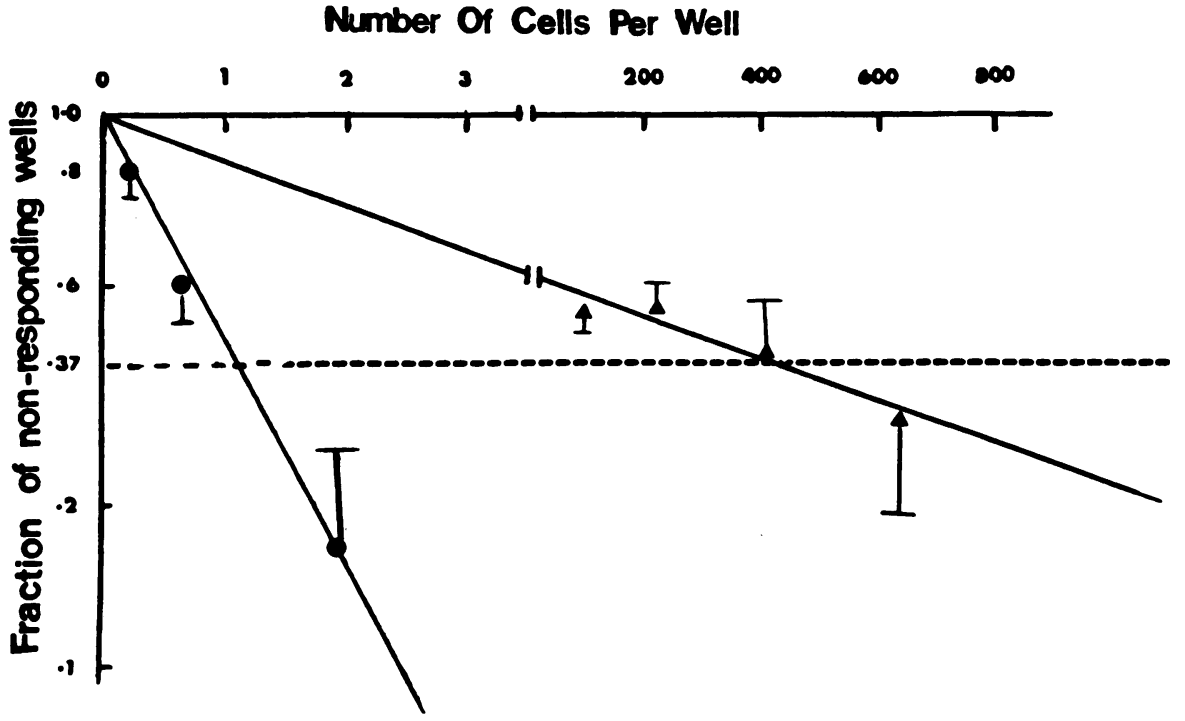

Figure 4. Frequency analysis of the precursors of IL-2-responsive T cells. Each point is based on a group of 24 replicate cultures of PBL from nine MG patients $(\bullet)$ and eight normal subjects $(\Delta)$. The dotted line (0.37) shows the cell concentration containing one clone per culture as determined by Poisson distribution analysis. normal subjects proliferated to AChR (Table VI). To assure that the proliferative responses reflected a selection and expansion of in vivo antigen-reactive $T$ cells and not an in vitro artifact due to the cloning procedure, the response of the clones to another autoantigen, MBP, was tested. This antigen produced positive proliferation in $30 \%$ of clones from MS patients (a representative data is shown in Table VII). None of the MG clones proliferated against MBP (Table VI), suggesting that the clones exhibited specificity to AChR- $\alpha$ chain. Clones from both MG patients and normal subjects also proliferated to rIL-2, indicating their IL-2 responsiveness (Table VI).

The clones were also tested for allospecific proliferative responses to $\mathrm{AChR}-\alpha$ chain, using both autologous and alloge-

Table V. Cell Surface Phenotypes of PBL-derived IL-2dependent T Cell Clones in MG Patients and Normal Subjects

\begin{tabular}{|c|c|c|}
\hline Name & Clone & Phenotype \\
\hline \multicolumn{3}{|c|}{ MG patients } \\
\hline L.B. & G11 & $\mathrm{CD}^{+} 4 \mathrm{~B}^{+}{ }^{+}$ \\
\hline D.P. & A4 & $\mathrm{CD}^{+} 4 \mathrm{~B}^{+}{ }^{+}$ \\
\hline M.L. & E1 & $\mathrm{CD}^{+} 4 \mathrm{~B} 4^{+} 2 \mathrm{H} 4^{+}$ \\
\hline P.M. & E10 & $\mathrm{CD}^{+} 4 \mathrm{~B} 4^{+}$ \\
\hline D.M. & E11 & $\mathrm{CD}^{+} 4 \mathrm{~B}^{+}{ }^{+}$ \\
\hline D.R. & B3 & $\mathrm{CD}^{+} 4 \mathrm{~B} 4^{+} 2 \mathrm{H} 4^{+}$ \\
\hline D.R. & $\mathrm{C} 8$ & $\mathrm{CD}^{+} 4 \mathrm{B4}^{+}$ \\
\hline D.P. & A8 & $\mathrm{CD}^{+}$ \\
\hline J.M. & H3 & $\mathrm{CD}^{+} 4 \mathrm{~B} 4^{+} 2 \mathrm{H}^{+}$ \\
\hline \multicolumn{3}{|c|}{ Normal subjects } \\
\hline \multirow[t]{2}{*}{ w.O. } & F7 & $\mathrm{CD}^{+} 4 \mathrm{~B}^{+}{ }^{+}$ \\
\hline & F6 & $\mathrm{CD}^{+} 4 \mathrm{~B} 4^{+}$ \\
\hline \multirow[t]{2}{*}{ F.M. } & D3 & $\mathrm{CD}^{+} 4 \mathrm{~B}^{+}{ }^{+}$ \\
\hline & D5 & $\mathrm{CD}^{+} 4 \mathrm{~B}^{+}{ }^{+}$ \\
\hline \multirow[t]{3}{*}{ M.P. } & E4 & $\mathrm{CD}^{+} 4 \mathrm{~B} 4^{+} 2 \mathrm{H}^{+}$ \\
\hline & E7 & $\mathrm{CD}^{+} 2 \mathrm{H}^{+}{ }^{+}$ \\
\hline & E2 & $\mathrm{CD}^{+} 4 \mathrm{~B}^{+} 2 \mathrm{H}^{+}$ \\
\hline B.H. & F2 & $\mathrm{CD}^{+} 4 \mathrm{~B}^{+} 2 \mathrm{H}^{+}{ }^{+}$ \\
\hline S.A. & E10 & $\mathrm{CD}^{+}$ \\
\hline
\end{tabular}

neic APC. The average proliferative response of $\mathrm{T}$ cell clones from MG patients, in the presence of autologous APC, was significantly higher than that of $T$ cell clones from normal subjects (Fig. 5). The positive proliferative response only occurred when AChR- $\alpha$ chain was presented with autologous APC, suggesting that the recognition of AChR- $\alpha$ chain by the MG clones was MHC restricted (Fig. 5). As shown in one representative experiment, the allogeneic APC obtained from one MS patient failed to elicit proliferation of MG clones to AChR- $\alpha$ chain but was capable of presenting MBP to T cell clones from the same MS patient (Table VII). About $10 \%$ of all clones produced "allogeneic" response with an average cpm of $1-3 \times 10^{3}$. None of these were antigen responsive and all were excluded from this study. To further define the nature of the MHC restriction of AChR- $\alpha$ chain-specific clones, antibodies to HLA-DR and HLA-ABC were added during the 72-h assay. Anti-HLA-DR but not anti-HLA-ABC inhibited the proliferation of two clones, indicating that they were class-II restricted (Fig. 6).

Cytotoxic activity of $T$ cell clones. Nine $T$ cell clones from patients with MG, eight from normal subjects and eight from patients with MS were examined for non-MHC restricted cytotoxicity by their capacity to kill K562 and Daudi target cells (Fig. 7). T cell clones from MG patients, MS patients, and normal subjects were not significantly different from each other in their levels of cytotoxicity against K562 target cells. T cell clones from MG patients were significantly less cytotoxic against Daudi cells than the clones from MS patients $(P$ $<0.03$ ) and marginally less cytotoxic than the $T$ cell clones from normal subjects $(P=0.05)$.

\section{Discussion}

In this report, the phenotypic and functional characteristics of peripheral blood $\mathrm{T}$ cells were studied to evaluate the regulatory role of $T$ cells in the pathogenesis of MG. First, the cell surface phenotypes of the PBL of MG patients were analyzed and it was found that MG patients had a significantly higher percentage of the helper-inducer subset of $\mathrm{T}$ cells $\left(4 \mathrm{~B} 4^{+}\right)$than normal subjects. Recent studies have indicated that the $\mathrm{CD}^{+}$and 
Table VI. Proliferative Responses of T Cell Clones from MG Patients and Normal Subjects

\begin{tabular}{|c|c|c|c|c|}
\hline \multirow[b]{2}{*}{ Clones } & \multicolumn{4}{|c|}{$\left[{ }^{3} \mathrm{H}\right] \mathrm{TdR}$ incorporation $\left(\times 10^{-3}\right) \pm \mathrm{SEM}$} \\
\hline & Medium only ${ }^{\ddagger}$ & $\mathrm{AChR}^{*}$ & IL-2 & MBP \\
\hline \multicolumn{5}{|l|}{ MG patients } \\
\hline G11 & $0.23 \pm 0.09$ & $17.26 \pm 3.48$ & $39.35 \pm 16.06$ & $0.20 \pm 0.04$ \\
\hline A4 & $0.23 \pm 0.31$ & $20.53 \pm 4.49$ & $50.09 \pm 4.53$ & $0.31 \pm 0.20$ \\
\hline E1 & $0.31 \pm 0.01$ & $11.61 \pm 0.40$ & $20.9 \pm 3.82$ & $0.43 \pm 0.01$ \\
\hline B3 & $0.08+0.02$ & $5.67 \pm 0.02$ & $21.72 \pm 0.00$ & $0.14 \pm 0.04$ \\
\hline $\mathrm{C} 8$ & $0.03+0.02$ & $8.07 \pm 0.01$ & $18.63 \pm 0.01$ & $0.02 \pm 0.03$ \\
\hline A8 & $0.28 \pm 0.30$ & $1.06 \pm 0.31$ & $24.63 \pm 5.93$ & $0.13 \pm 0.03$ \\
\hline H3 & $0.25 \pm 0.02$ & $1.82 \pm 0.53$ & $9.74 \pm 4.27$ & $0.24 \pm 0.10$ \\
\hline \multicolumn{5}{|c|}{ Normal subjects } \\
\hline E4 & $1.20+1.01$ & $0.35+0.09$ & $46.21+3.92$ & $0.42+0.01$ \\
\hline E7 & $1.13+0.03$ & $0.19+0.09$ & $56.24+1.41$ & $0.51+0.05$ \\
\hline E2 & $0.14 \pm 0.07$ & $0.14 \pm 0.08$ & $10.53 \pm 2.75$ & ND \\
\hline $\mathbf{F} 2$ & $1.23+0.82$ & $0.13+0.03$ & $17.84+0.42$ & $0.21+0.05$ \\
\hline E10 & $0.23+0.04$ & $0.31+0.01$ & $35.92+2.45$ & $0.33+0.02$ \\
\hline
\end{tabular}

* $P=0.002 \mathrm{MG}$ patients higher than normal subjects. ${ }^{\ddagger}$ Medium only consists of APC $+\mathrm{T}$ cell clones.

$\mathrm{CD}^{+}$populations of $\mathrm{T}$ cells can be subdivided into two distinct subsets, $2 \mathrm{H}^{+} 4 \mathrm{~B} 4^{-}$and $2 \mathrm{H}^{-} 4 \mathrm{~B} 4^{+}$, using monoclonal antibodies and functional studies (11-13). The former subset suppressed PWM-driven Ig synthesis and was hence designated suppressor-inducer, whereas the latter subset functioned as a classical helper cell. Our findings in MG are in contrast to those in patients with MS and rheumatoid arthritis, in whom the percentage of suppressor-inducer cells $\left(2 \mathrm{H}^{+}\right)$was significantly lower than in normal subjects $(27,28)$. Although the percentage of suppressor-inducer $T$ cell subset in patients with MG was also lower than in normal subjects, this difference was not statistically significant.

The cellular and antibody responses of MG patients and normal subjects to the $\alpha$ chain of AChR were analyzed. The serum antibody level was higher in $88 \%$ of the MG patients than in normal subjects. Anti-AChR antibodies and their pathologic role in MG have been studied extensively (29). In vitro synthesis of anti-AChR antibodies in cultures of unstimulated and PWM -stimulated PBL was shown to be significantly higher in MG patients than in normal controls (30). The mechanisms responsible for the emergence and regulation of this autoantibody are not yet understood. Our studies indicate that PBL B cells from MG patients secreted antibody to AChR- $\alpha$ chain in vitro, only when cultured with autologous $T$ cells. The lymphoproliferative response of MG PBL to Torpedo AChR- $\alpha$ chain, was higher than PBL from normal subjects. $65 \%$ of PBL from MG patients showed proliferative responses to this antigen, compared with $9 \%$ of normal subjects.

Table VII. ACHR-specific T Cell Clones Are MHC Restricted

\begin{tabular}{|c|c|c|c|c|c|}
\hline \multirow[b]{2}{*}{ T cell clones } & \multicolumn{4}{|c|}{$\left[{ }^{3} \mathrm{H}\right] \mathrm{TdR}$ incorporation $\left(\times 10^{-3}\right) \pm \mathrm{SEM}^{*}$} & \multirow[b]{2}{*}{ MBP } \\
\hline & APC & Medium & $\mathrm{AChR}$ & IL-2 & \\
\hline DR-B3 & Autologous & $0.1 \pm .00$ & $6.57 \pm .02$ & $5.28 \pm .02$ & $0.07+0.06$ \\
\hline (MG) & Allogeneic & $0.3 \pm .07$ & $0.2 \pm .03$ & $5.19 \pm .01$ & ND \\
\hline DR-C8 & Autologous & $0.1 \pm .02$ & $10.2 \pm .01$ & $4.56 \pm .01$ & $0.1+.03$ \\
\hline (MG) & Allogeneic & $0.1 \pm .00$ & $0.03 \pm .00$ & $8.2 \pm .04$ & ND \\
\hline B-H1 & Autologous & $0.2 \pm .02$ & $0.2+.02$ & $15.7 \pm .01$ & $16.9 \pm .01$ \\
\hline (MS) & Allogeneic & $0.5 \pm .12$ & ND & $16.3 \pm .02$ & $0.7 \pm .16$ \\
\hline B-B10 & Autologous & $0.2 \pm .05$ & $0.2+.03$ & $20.8 \pm .17$ & $24.7 \pm .04$ \\
\hline (MS) & Allogeneic & $0.4 \pm .13$ & ND & $22.1 \pm .01$ & $0.41 \pm .09$ \\
\hline
\end{tabular}

\footnotetext{
* Proliferative responses were performed as described in Methods. ${ }^{\ddagger}$ The source of allogeneic APC for the MG clones were APC from PBL of MS patient, and vice versa.
} 


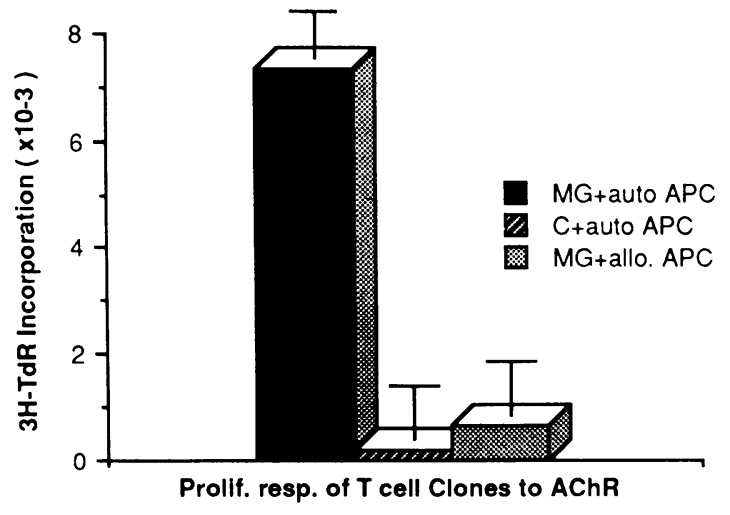

Figure 5. MHC restriction of $\mathrm{T}$ cell responses. The proliferative responses $\left(\left[{ }^{3} \mathrm{H}\right]\right.$ thymidine uptake) to purified $\mathrm{AChR}-\alpha$ chain, of nine $\mathrm{T}$ cell clones from MG patients, in the presence of autologous and allogeneic APC $(P<0.001)$ and of nine T cell clones from normal subjects $(C)$ in the presence of autologous $\operatorname{APC}(P<0.005)$.

Melms et al. (10) found thymic T cells from all $10 \mathrm{MG}$ patients tested to be responsive to AChR, whereas only 3 of 10 PBL were reactive (10). The ability of different peptide subunits of human AChR- $\alpha$ chain, to stimulate PBL T cells from MG patients was tested in two different laboratories $(6,9)$. There are conflicting results, however, on which peptides significantly discriminate between $T$ cell responses from MG patients and normal subjects. Only one of the peptides (residue 257-269) of the $\alpha$ subunit was found by both laboratories to evoke a proliferative response of $T$ cells of MG patients. The majority of MG patients, and a few normal subjects, responded to more than one peptide in both the proliferative and antibody assays (6), indicating the heterogeneity of the response.

In this study, 9 of $19 \mathrm{~T}$ cell clones, obtained from seven MG patients, exhibited positive proliferative responses to purified AChR- $\alpha$ chain from Torpedo californica. This data is consistent with results obtained by other investigators (7-10). None of the clones responded to the irrelevant antigen, BSA, or to another autoantigen MBP, suggesting an antigen-specific recognition by the clones. None of the nine $T$ cell clones obtained from eight normal subjects proliferated to the AChR- $\alpha$ chain. Hohlfeld et al. (7) were able to isolate T cell lines from
MG patients in the presence of Torpedo AChR. Using three synthetic peptides corresponding to the $\mathrm{NH}_{2}$ terminal of human $\mathrm{AChR}$, they found that different peptides were recognized by different $\mathrm{T}$ cell lines, indicating that the $\mathrm{T}$ cell autoimmune response in MG is heterogenous (7). Melms et al. (10), also using Torpedo AChR, isolated $\mathrm{CD}^{+}{ }^{+} \mathrm{T}$ cell lines from thymuses of MG patients. All of these studies (7-10) have used T cell lines rather than clones. Using the LDA (23) in the presence of rIL-2 and in the absence of putative autoantigen, $\mathrm{AChR}$, we isolated antigen-reactive $\mathrm{T}$ cell clones only from the PBL of MG patients and not from the PBL of normal subjects. This is at variance with the findings of others $(4,5)$ who isolated $T$ cell lines with low reactivity to AChR from normal human blood. In these studies, however, the MNC were stimulated with $A C h R$ before establishing the $T$ cell line and so it is difficult to infer whether the AChR-reactive cells obtained during culture were generated from naive $\mathrm{T}$ cells or were the result of the expansion of preexisting reactive cells in the starting population.

In the present study, we have demonstrated, for the first time, that $\mathrm{AChR}$-responsive $\mathrm{CD}^{+}$and $\mathrm{CD} 8^{+} \mathrm{T}$ cell clones can be isolated and expanded in vitro only from the peripheral blood of MG patients and not from normal subjects. The technique employed for the generation of $\mathrm{T}$ cell clones appears to be preferable to other techniques for studies on autoreactive $T$ cells in autoimmune diseases. The technique employed, however, selected for $\mathrm{CD}^{+} \mathrm{T}$ cell clones in the PBL of normal subjects and, to a lesser extent, of MG patients. While CD4 T cells are more than twice as numerous as CD8 T cells in PBL of both MG patients and normal subjects, the clones that were obtained were $90 \%$ CD8 in normal subjects and $44 \%$ in MG patients. This may be due to selective pressures in the culture system, such as the presence of rIL-2 as the only lymphokine, which facilitates the growth of $\mathrm{CD}^{+}$cells over $\mathrm{CD}^{+}$cells. T cell clones from MG patients and normal subjects were further analyzed for the expression of surface antigens, 4B4 and $2 \mathrm{H} 4$. About $50 \%$ of $\mathrm{T}$ cell clones from each group were found to be $4 \mathrm{~B} 4^{+}$and $33 \%$ were positive for both antigens. It is quite clear, from other studies as well, that the expression of these two antigens on the surface of $T$ cells is not mutually exclusive (31). Other studies have shown that peripheral blood $\mathrm{T}$ cells lost CD45R (2H4) and acquired CDw29 (4B4) antigen when activated in vitro with PHA (32), indicating that $2 \mathrm{H} 4 \mathrm{~T}$ cells are naive cells that differentiate to mature $T$ cells with the

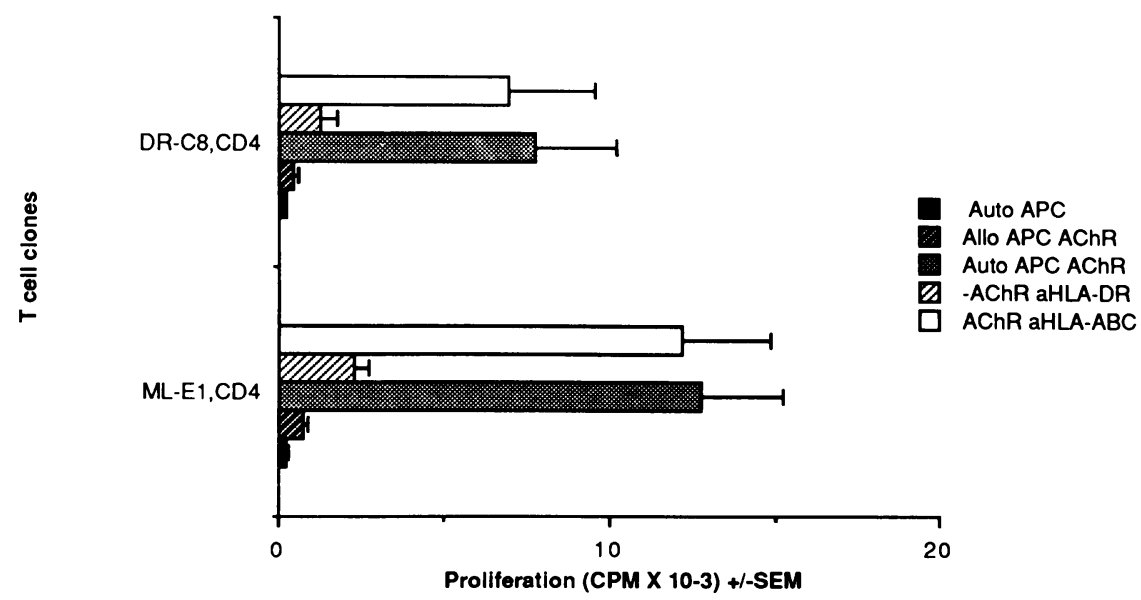

Figure 6. HLA-DR restriction of $\mathrm{T}$ cell clones. Effects of anti-HLA-DR and anti-HLA-ABC antibody on the proliferation of $\mathrm{T}$ cell clones from MG patients to AChR- $\alpha$ chain. 


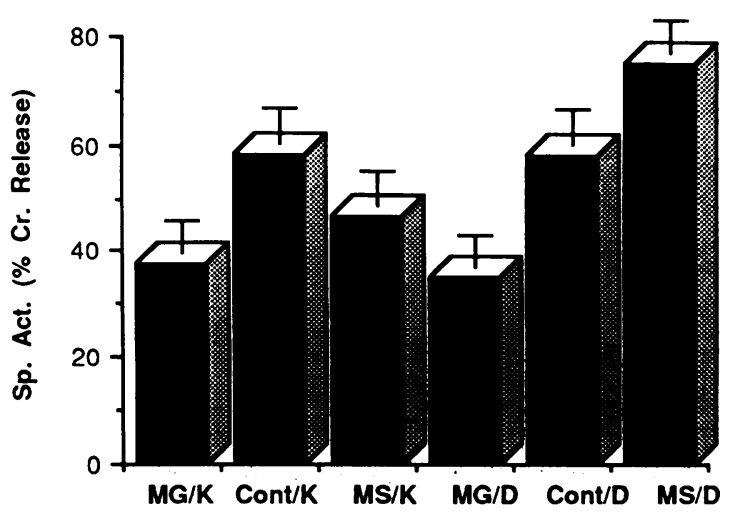

Figure 7. Cytotoxic responses of $\mathrm{T}$ cell clones. Percent cytotoxic activity $\left({ }^{51} \mathrm{Cr}\right.$ release) of nine $\mathrm{T}$ cell clones from MG patients (AChR- $\alpha$ chain-responsive), nine normal subjects (Cont), and eight MS patients towards K562 (K) and Daudi (D) target cells. The effector/target ratio was 10:1. The statistically significant values are: $P<0.03$ (MS/D higher than Cont/D), $P=0.05$ (MG/D lower than Cont/D) and $P<0.03$ (MG/D lower than MS/D).

expression of 4B4. These studies, however, used purified CD4 ${ }^{+}$ cells and PHA, which being a polyclonal $\mathrm{T}$ cell mitogen will presumably cause the maturation of naive $T$ cells. In contrast, our studies used only IL-2 to select for spontaneously activated $\mathrm{T}$ cells which may be differentiating further in vitro.

The precursor frequency of IL-2-responsive clones was much higher in MG patients than normal subjects, indicating that MG patients may have a larger pool of spontaneously activated cells in the PBL which can readily be cloned with high frequency. Our findings also suggest that long-term IL-2dependent $T$ cell clones can retain their antigen reactivity through activation with PHA and APC in the absence of the putative antigen. This is consistent with other studies which have shown that $\mathrm{T}$ cells maintained on APC and IL-2 alone, and/or on CD3 antibody, retained their antigenic specificity and reactivity $(33,34)$.

The MG clones in this study did not exhibit significant non-MHC restricted cytotoxicity, as compared to the controls, in being able to kill K562 (NK-sensitive) and Daudi (NK-resistant) targets. This finding is in contrast with the findings of others that $\mathrm{CD}^{+}$and $\mathrm{CD} 8^{+} \mathrm{T}$ cell clones activated with PHA (35), or cloned in IL-2 medium, express non-MHC-restricted cytotoxicity $(36,37)$ in being able to kill a variety of tumor targets. In our laboratory, we have found that IL-2-responsive clones obtained from MS patients expressed non-MHC-restricted cytotoxicity (manuscript submitted for publication). The absence of significant cytotoxic activity in $T$ cell clones from MG patients suggests that the PBL T cells play their role in the pathogenesis of MG, not by cytotoxicity, but more likely by their demonstrated ability to stimulate antibody production by $B$ cells.

Based on previous studies on cloned normal $\mathrm{T}$ cell populations, these cells could be grouped into at least two types. One helped specific B cell responses, but failed to mediate killing and suppression of delayed-type hypersensitivity, while the other suppressed specific antibody response, mediated delayed-type hypersensitivity and killed appropriate target cells (38). These functional distinctions have led to the designation of the first set as helper T cells/TH2 and the latter as inflammatory $\mathrm{T}$ cells/TH1. Using anti-CD45R antibody, these two functional populations were found to be CD45R-low (or 4B4 ${ }^{+}$ in humans) in helper and CD45R-high (2 $\mathrm{H}^{+}$in humans) in inflammatory subset of $T$ cells (38).

In summary, $T$ cells from MG patients expressed a higher density of 4B4 antigen than normal subjects and were much more readily cloned than $T$ cells of normal subjects. The MG $\mathrm{T}$ cell clones were highly proliferative to AChR- $\alpha$ chain, the putative autoantigen, helped the production of specific antiAChR antibody by autologous B cells, but did not express significant cytotoxic activity against target cells. $\mathrm{T}$ cell clones from normal subjects did not proliferate or make antibody, in similar experiments, to AChR- $\alpha$ chain. It appears that the T cells from MG patients are of TH2/helper category. Based on the above observations, the two phenotypically and functionally different subpopulations of $T$ cells which exist in vivo for both CD4 and CD8 T cells, 4B4 and 2H4, probably play major roles in the immunoregulatory circuit (39). Changes in the proportions and numbers of these antigen-activated cells may be major factors in the pathogenesis of myasthenia gravis and perhaps other autoimmune diseases.

\section{Acknowledgment}

We gratefully acknowledge Dr. K. Krolich for his protocol for the purification of AChR and the assistance of Ada Lee and Drs. B. Hoch and D. Azad.

This work was supported by grants R29NS24688 from the National Institutes of Health, and RG 1004-A-1 from the National Multiple Sclerosis Society and by a grant from the Maimonides Research and Development Foundation.

\section{References}

1. Patrick, J., and J. Lindstrom. 1973. Autoimmune response to acetylcholine receptor. Science (Wash. DC). 180:871-872.

2. Lindstrom, J. M., A. G. Engel, M. E. Seybold, V. A. Lennon, and E. H. Lambert. 1976. Pathological mechanisms in experimental autoimmune myasthenia gravis. J. Exp. Med. 144:739-753.

3. Richman, D., J. Patrick, and B. G. W. Arnason. 1976. Cellular immunity in myasthenia gravis. N. Engl. J. Med. 294:694-698.

4. Conti-Tronconi, B. M., M. Morgutti, A. Sghilanzoni, and F. Clementi. 1979. Cellular immune response against acetylcholine receptor in myasthenia gravis: relevance to clinical course and pathogenesis. Neurology. 29:496-501.

5. Hohlfeld, R., K. V. Toyka, K. Heininger, H. Gross-Wilde, and I. Kalies. 1984. Autoimmune human T lymphocytes specific for acetylcholine receptor. Nature (Lond.). 310:244-2.

6. Brooke, S., C. Brautbar, L. Steinman, O. Abramsky, J. Rothbard, D. Neumann, S. Fuchs, and E. Mozes. 1988. In vitro proliferative responses and antibody titers specific to human acetylcholine receptor synthetic peptides in patients with myasthenia gravis and relation to HLA class II genes. J. Clin. Invest. 82:1894-1900.

7. Hohlfeld, R., I. Kalies, B. Kohleisen, K. Heininger, B. M. Conti-Tronoconi, and K. V. Toyka. 1986. Myasthenia gravis: stimulation of anti-receptor auto-antibodies by autoreactive T cell lines. Neurology. 36:618-621.

8. Hohlfeld, R., K. V. Toyka, L. L. Miner, S. L. Walgrave, and B. M. Conti-Tronconi. 1988. Amphipathic segment of the nicotinic receptor alpha subunit contains epitopes recognized by $\mathrm{T}$ lymphocytes in myasthenia gravis. J. Clin. Invest. 81:657-660.

9. Harcourt, G. C., N. Sommer, J. Rothbard, H. N. A. Willcox, and J. Newsom-Davis. 1988. A juxta-membrane epitope on the human acetylcholine receptor recognized by $\mathrm{T}$ cells in myasthenia gravis. $J$. Clin. Invest. 82:1295-1300.

10. Melms, S., B. C. G. Schalke, T. Kirchner, H. K. Muller-Her- 
melink, E. Albert, and H. Wekerle. 1988. Thymus in myasthenia gravis: Isolation of T-lymphocyte lines specific for the nicotinic acetylcholine receptor from thymuses of myasthenic patients. J. Clin. Invest. 81:902-908.

11. Thomas, Y., J. Sosman, and O. Irigoyen. 1980. Functional analysis of human $T$ cell subsets defined by monoclonal antibodies. I. Collaborative T-T interactions in the immunoregulation of $B$ cell differentiation. J. Immunol. 125:2402-2408.

12. Morimoto, C., E. L. Reinherz, Y. Borel, and S. F. Schlossman. 1983. Direct demonstration of the human suppressor-inducer subset by anti-T cell antibodies. J. Immunol. 130:157-161.

13. Reinherz, E. L., C. Morimoto, K. A. Fitzgerald, and S. F. Schlossman. 1982. Heterogeneity of human T4 inducer $T$ cells as defined by a monoclonal antibody that delineates two functional subpopulations. J. Immunol. 128:463-468.

14. Krolick, K. A., and O. E. Urso. 1986. Influence of T cell specificity on the antibody response to the acetylcholine receptor. $J$. Neuroimmunol. 13:75-87.

15. Yeh, T. M., and K. A. Krolick. 1987. Influence of T cell specificity on the heterogeneity and disease-causing capability of antibody against the acetylcholine receptor. J. Neuroimmunol. 17:17-34.

16. Lindstrom, J. 1977. An assay for antibodies to human acetylcholine receptor in serum from patients with myasthenia gravis. Clin. Immunol. Immunopathol. 7:36-43.

17. Boyum, A. 1968. Isolation of mononuclear cells and granulocytes from human blood. Scand. J. Clin. Lab. Invest. 21 (Suppl. 97):77-82.

18. Welch, A., J. H. Holda, and R. H. Swanborg. 1980. Regulation of experimental allergic encephalomyelitis. J. Immunol. 125:186-189.

19. Madsen, M., H. E. Johnsen, P. W. Hansen, and S. E. Christiansen. 1980. Isolation of human T and B lymphocytes by E-rosette gradient centrifugation: characterization of the isolated subpopulations. J. Immunol. Methods. 33:323-336.

20. Rosenkoetter, M., A. T. Reder, J. J. Oger, and J. P. Antel. 1984. $T$ cell regulation of polyclonally induced immunoglobulin secretion in humans. J. Immunol. 132:1779-1783.

21. Mokhtarian, F., D. Grob, and D. E. Griffin. 1987. Role of the immune response in Sindbis virus-induced paralysis of $\mathrm{SJL} / \mathrm{J}$ mice. $J$. Immunol. 143:633-637.

22. Carteron, N. L., C. L. Schimenti, and D. Wofsy. 1989. Treatment of murine lupus with $\mathrm{F}(\mathrm{ab})_{2}$ fragment of monoclonal antibody to L3T4. J. Immunol. 142:1470-1475.

23. Vie, H., M. Bonneville, P. Sondermeyer, J. R. Moreau, and J. P. Soulillou. 1986. Limiting dilution analysis (LDA) of cells responding to recombinant interleukin-2 without previous stimulation: evidence that all responding cells are lymphokine-activated potent effectors. Immunology. 57:351-357.

24. Tedder, T. F., M. D. Cooper, and L. T. Clement. 1985. Human lymphocyte differentiation antigens HB-10 and HB-11. II. Differential production of $B$ cell growth and differentiation factors by distinct helper cell subpopulations. J. Immunol. 134:2989-2994.

25. Rayner, A. A., E. A. Grimm, M. T. Lotze, D. J. Wilson, and
S. A. Rosenberg. 1985. Lymphokine-activated killer (LAK) cell phenomenon. IV. Lysis by LAK cell clones of fresh human tumor cell from autologous and multiple allogeneic tumors. J. Natl. Cancer Inst. 75:67-75.

26. Lefkovitz, I., and T. Waldman, 1979. Limiting dilution Analysis of Cells in the Immune System. Cambridge University Press, Cambridge, UK.

27. Morimoto, C., D. Hafler, H. Weiner, N. L. Letvin, M. Hagan, J. Daley, and S. F. Schlossman. 1987. Selective loss of the suppressor-inducer T-cell subset in progressive multiple sclerosis. $N$. Engl. J. Med. 316:67-72.

28. Emery, P., K. C. Gentry, I. R. MacKay, K. D. Muirden, and M. Rowley. 1987. Deficiency of the suppressor-inducer subset of T lymphocytes in rheumatoid arthritis. Arthritis Rheum. 30:850-856.

29. Drackman, D. B., S. De Silva, D. Ramsy, and A. Pestronk. 1987. Humoral pathogenesis of myasthenia gravis. Ann. N.Y. Acad. Sci. 505:90-106.

30. Lisak, R. P., A. I. Levinson, B. Zweiman, and M. J. Kornstein. 1987. In vitro synthesis of IgG and antibodies to AChR by peripheral and thymic lymphocytes. Ann. N.Y. Acad. Sci. 505:39-50.

31. Morimoto, C., N. L. Letvin, A. W. Boyd, M. Hagan, H. M. Brown, and S. F. Schlossman. 1985. Isolation and characterization of the human helper-inducer T cell subset. J. Immunol. 134:3762-3769.

32. Serra, H. M., J. A. Ledbetter, J. F. Kowka, and L. M. Pilarski. 1988. Loss of CD45R (Lp220) represents a post-thymic T cell differentiation event. J. Immunol. 140:1435-1441.

33. Clark, R. B., E. G. Ligenheld, J. O. Donaldson, and M. K. Pollard. 1985. Compartmentalized immune responses: antigen-specificity of cerebrospinal fluid $\mathrm{T}$ cell lines maintained in the absence of antigen. Clin. Immunol. Immunopathol. 36:176-186.

34. Padula, S. J., M. K. Pollard, E. G. Lingenheld, and R. B. Clark. 1985. Maintenance of antigen-specificity by human interleukin- 2 dependent $T$ cell lines. Use of antigen-presenting cells and OKT3 antibody in the absence of antigen. J. Clin. Invest. 75:788-797.

35. Patel, S. S., D. L. Thiele, and P. E. Lipsky. 1987. Major histocompatibility complex-unrestricted cytolytic activity of human $\mathrm{T}$ cells. Analysis of precursor frequency and effector phenotype. J. Immunol. 139:3886-3895.

36. Brooks, C. G., D. L. Urdal, and C. S. Henney. 1983. Lymphokine driven "differentiation" of cytotoxic $\mathrm{T}$ cell clones into cells with NK-like specificity. Correlation with display of membrane macro-molecules. Immunol. Rev. 72:43-72.

37. Grimm, E. A., R. J. Robb, J. A. Roth, L. M. Neckers, L. B. Lachman, D. J. Wilson, and S. A. Rosenberg. 1983. Lymphokine-activated killer cell phenomenon. III. Evidence that IL-2 is sufficient for direct activation of peripheral blood lymphocytes into lymphokineactivated killer cells. J. Exp. Med. 158:1356-1361.

38. Bottomly, K. 1988. A functional dichotomy in $\mathrm{CD}^{+} \mathrm{T}$ lymphocytes. Immunol. Today. 9:268-274.

39. Morimoto, C., N. L. Letvin, J. A. Distato, W. R. Aldrich, and S. F. Schlossman. 1985. The isolation and characterization of the human suppressor-inducer T-cell subset. J. Immunol. 134:1508-1515. 